\title{
THE EVOLUTION OF AN INDUSTRIAL SOCIETY
}

BY

\section{MAJOR GREENWOOD}

It is always difficult, when thinking of the evolution of a social or economic system, to free ourselves from the tyranny of illusions. No intelligent person now believes in a Golden Age thousands of years ago. It was not polite of Dr. Johnson, when Lord Monboddo-who did believe in a Golden Agepointing to his ancient house said, 'In such houses, our ancestors lived who were better men than we,' to reply, 'No, no, my lord, we are as strong as they, and a great deal wiser.' But, intellectually, we all agree with the doctor. Emotionally, however, we react differently.

Perhaps, because one of the most beautiful passages in Roman literature is an eulogy of an agricultural labourer's life (Vergil. Georg. II, 458474); perhaps, because some of us-like the author of the poem-have earned in cities the means of living in the country without being agricultural labourers, we do look back upon England before the 'Industrial Revolution' with regret. Certainly intelligent men could, without being romantic poets have that feeling at the end of the 18th century. It was not a poet but a statesman who wrote:

The monks are lazy. Be it so. Suppose them no otherwise employed than by singing in the choir. They are as usefully employed as those who neither sing nor say. As usefully even as those who sing upon the stage. They are as usefully employed as if they worked from dawn to dark in the innumerable servile, degrading, unseemly, unmanly, and often most unwholesome and pestiferous occupations, to which by the social economy so many wretches are inevitably doomed. If it were not generally pernicious to disturb the natural course of things, and to impede, in any degree, the great wheel of circulation which is turned by the strangely directed labour of these unhappy people, I should be infinitely more inclined forcibly to rescue them from their miserable industry, than violently to disturb the tranquil repose of monastic quietude. Humanity, and perhaps policy, might better justify me in the one than in the other !

Those lines were wi itten in 1790 , more than 40 years before any State-paid factory inspectors were appointed to report how children were used in factories. The first limitation, by enactment, of the hours of labour of adults came more than a century after Burke's death. That much happened to justify the language quoted, the most superficial reader of our economic history knows. Whether the 'poor' were happier, more free from disease, more sturdy, better fed in the first than in the last quarter of the 18 th century is not a question so easily answered affirmatively as poets suggest. The death rate of a country is not an infallible test; it is, however, $a$ test. By that criterion, England was healthier at the end than the beginning of the 18th century and indeed continued throughout the Sturm und Drang of the struggle for existence against Bonaparte to be healthier than it was ever to be again until a time within the memory of some now living.

At the beginning of the 18th century the gross death rate was between 26 and 29 per 1000 per annum and gradually increased to a figure between 33 and 36 towards the middle of the century. The rates continued about this level until the last decennium, when a decline began.

A minimum was reached between 20 and 24 per 1000. After the peace of 1815 the death rate rose and, throughout the registration period-viz. after 1839 - to the decennium 1871-80, was about 22.0 per 1000. Improvement began in 1871-80 and has continued ever since.

Statistically exact comparisons are impossible, because the data for the 18 th century are incomplete and the age constitution of the people has changed. But there is no doubt that the figures quoted are of the right order of magnitude ; in particular it is certain that in the last ten years of the 18 th century the rate of mortality was improving considerably and that, in spite of set-backs in particular years, the civilian population was healthier during the war of 1793-1815 than before or since (down to 1871-80).

Although 'obvious' explanations are often false, I think the 'obvious' explanation, viz. that the working classes were economically better off in the years of war expenditure, is right. But we must remember that 18 th- and early 19 th-century industry was still the employment of a minority, and there is adequate evidence that, in the highly industrialized North-West, rates of mortality exceeded those of the East and South.

At the end of the 18th century (the census of 1801) 7.6 per cent. of the English population was in Lancashire and 6.3 per cent. in the West Riding of Yorkshire; by 1841 these proportions had increased to 10.5 and 7.3 per cent. We have no adequate data of regional mortality before registration, but in 
1841-50 when the general death rate was 23 per 1000 , that of Lancashire was 28 per 1000 and of London 25 per 1000.

It is important, too, to realize that the evils of industrialization which first horrified our professional ancestors, were the indirect evils, not the factory but the domestic environment of the workers: their squalid, horrible, living quarters. It is only too easy to put on blinkers, to see nothing but the home or nothing but the working place. The evils of long hours of labour, of brutal oppression, of ghastly accidents due to reckless disregard of dangers, are more dramatic than the squalid misery of homes but, in our study, not more important. Perhaps they are less important.

It is probable that before 1870 (the Factory Act of 1867 strengthened and consolidated the powers of a generation of Acts, and inspection had been effective for more than a generation) the evils which had shocked the public conscience in pre-Victorian days were memories. Chadwick's campaign against domestic and communal insanitation had been less successful than that of Sadler and Lord Shaftesbury against the exploitation in factories of 'hands.' The general death rate of England and Wales remained higher than it had been in the laissez faire epoch of 1800-15. Had our ancestors wholly neglected the evils of life in factories, left young persons without the protection of laws and inspectors, disregarded extra-domestic evils but rehoused the people, I think the rate of mortality would have begun to fall a century sooner.

This is not a sneer at the efforts of men quite as intelligent and humane as any now living. Probably a great majority of them would have agreed with it but urged, quite correctly, that the best should not be made the enemy of the good. Public opinion 150 years ago was ready to react against the exploitation of children in factories; far from ready to admit that the castle, the proverbial home of every Englishman, was often a horrible den and must continue to be a horrible den, failing a revolutionary change in methods of government and in economic dogmas respecting the sanctity of property.

It may seem that, even within its emotionally accessible range, public opinion reacted slowly. Before the end of the 18th century, the evil of childlabour had been denounced by responsible authors; but in 1832 publicists were still at the Royal Commission or Departmental Committee stage.

In 1796 Perceval submitted to the Manchester Board of Health resolutions which deserve the hackneyed adjective classical. The following passage is almost too familiar to be quoted:

The untimely labour of the night, and the protracted labour of the day, with respect to children, not only tends to diminish future expectations as to the general sum of life and industry by impairing the strength and destroying the vital stamina of the rising generation, but it too often gives encouragement to idleness, extravagance, and profligacy in the parents who, contrary to the order of nature, subsist by the oppression of their offspring.

Yet more than 30 years passed before any effective measures were taken by the central government.

The explanation is, I think, contained in a less frequently quoted passage of the document:

From the excellent regulations which subsist in several cotton factories, it appears that many of these evils may, in a considerable degree, be obviated; we are therefore warranted by experience, and are assured we shall have the support of the liberal proprietors of these factories, in proposing an application for Parliamentary aid (if other methods appear not likely to effect the purpose), to establish a general system of laws for the wise, humane and equal government of all such works.

It is not praising ourselves too much to say that British public opinion has nearly always been a generation in advance of its legislative expression. Simon and other writers have pointed out how potent was a growing spirit of humanity in moulding practice before legislative coercion. Indeed, systems which, on paper, have simply nothing to recommend them do not always work badly. Any reader of those novels of Marryat which were written for adults-for instance the really horrible account of the sadistic captain flogging a man for pleasure (Frank Mildmay, Chap. XVI)-might see in Johnson's remark,

'No man will be a sailor who has contrivance enough to get himself into a "jail,", another instance of the Doctor's luminous common sense. But the fact that we still survive as a nation, or even the general tone of Marryat's writing, show that in a service where there was virtually no control, except public opinion, over beastliness which a Nazi might envy, life was, statistically speaking, endurable, often happy.

The Health and Morals of Apprentices Act (1802) is usually accepted as the commencement of factory legislation, although it was in form simply an extension of the Elizabethan Poor Law. Hours of labour for these children were not to exceed 12 daily, and a duty of visitation was imposed on Justices of the Peace. In 1819 the employable age of children was fixed at 9 years. None under 16 should work more than 12 hours. Night work was forbidden.

In 1825 the working time on Saturdays was reduced to 9 hours. In 1831, the age of limitation was raised to 18 and prohibition of night work extended to all persons aged less than 21 .

The Act of 1833 marked a considerable advance; the earlier Acts applied only to cotton mills, this extended legislation to woollen, worsted, hemp, flax, tow, linen and silk factories. Children under 13 must not work more than 9 hours a day or 48 hours in any week, and nobody under 18 but over 13 (now called a young person) might work more than 69 hours a week or be employed at night. 
Medical practitioners were to be judges of age and inspectors, appointed and paid by the State, were to supervise the working of the law.

The inspectors found that the provisions respecting age of the Act of 1833 were not effective and themselves appointed certifying surgeons, a proceeding legalised in 1844. The Act of this year first made provision for the fencing of mill-gearing and shafting and, for the first time, women were included with young persons in the limitation of hours. Another innovation was the half-time system for children of, at least, 8 years.

The famous 10 hours Act of 1847, although concerned wholly with hours of employment, is justly thought to mark an epoch. Young persons and women must not be worked more than 10 hours a day or 58 hours a week; the permitted times were between 5.30 a.m. and 8.30 p.m. Indirectly this Act limited the hours of labour of men; although attempts at evasion-for instance by employing relays of protected persons-were made. An Act of 1850 endeavoured to meet this. Hours of work were to be either from 6 a.m. to $6 \mathrm{p} . \mathrm{m}$. or from 7 a.m. to 7 p.m. with an hour and a half for mealtime within these hours; on Saturdays work was to cease on 2 p.m. This gave a normal working week of 60 hours.

The next important date in the history of legislation is 1867. An Act of that year not only extended the connotation of factories but required mechanical means of removing dust evolved in a manufacturing process which might be inhaled to an injurious extent. It is probable that this provision was inspired by the researches of Greenhow carried out at the request of Simon. In the same year workshops, defined as industrial establishments employing less than 50 persons, were subjected to regulation. Finally we have, at the beginning of the 20th century, the Consolidating Factory and Workshops Act of 1901 which, without introducing any fundamentally new principles, simplified and improved administration.

To reach a conclusion as to the precise effect of changes in the conditions of work on the well-being of the employees through the half century ending in 1901 is difficult. We can, of course, compare the death rates in geographical areas, the inhabitants of which are known to have been mostly employed in factory industry, for instance in the textile towns (vide infra) through the decennia from 1851-60 to the end of the century. Changes are, however, resultants of several components: (1) Factory conditions, (2) Housing conditions, (3) Personal hygiene and morale.

What seems an obvious statistical short-cut, viz. to use analyses of occupational mortality rates, which were begun by Farr more than seventy years ago, is something of a blind alley. Here are some of the difficulties. There has been a great increase in the number of occupations studied and in the accuracy of their definition. In Farr's pioneer report of 1851 , only 11 occupations were chosen. Now the analysis is complete.
The early classification is vague. Take, for example, the classical instance of industrial silicosis, a hazard recognized in the 16th century (metalliferous miners) and well described in the cutlery industry more than a century ago. Improvements, embodied in legislation, have lessened the danger of inhalation of potentially noxious dust. Can we say, statistically, that workers in silicosis trades are better off than seventy years ago? We may be convinced on the basis of general experience that they are, but we cannot make a statistical proof. Farr had a group of tool file and saw makers, dealers (data of 1861 and 1871). Employing the modern method of statement, their comparative mortality figure was 137 . But this group, while certainly including many persons exposed to special hazards, also includes many (dealers) not at special risk. If one takes from the 1931 analysis file cutters, filers, cutlery grinders and cutlers, their relative mortality figure is 159 . But this set is confined to persons certainly exposed to risk. There is no valid comparison with the figures of sixty years before; like is not compared with like.

This is not all. An occupational mortality rate may be high, not because of specific hazards but because of its low economic status or because, for geographical reasons, those employed in it are badly housed. It is only in recent times that analysis by economic status has been attempted.

For the first time in 1931, the mortality rates of the wives of occupied men have been analysed giving a valuable index of the economic-domestic factor. Those who come after us will be more fortunate than we; we have to face the position, viz. that judgment on the past depends on uncertain and confused data. That is why different writers reach wholly different general conclusions. A writer's emotional bias affects his choice of evidence. My own bias leads me to stress what I called above personal hygiene and morale.

One evil of child labour stressed by our ancestors was the impossibility of educating wearied children. A great majority of those who took this point were thinking mainly of religious instruction; perhaps they were wiser than clever young men think, but I shall speak only of the literary instruments.

Our statistical predecessors did not go deeply into educational returns. This question, however, did not escape the notice of William Farr, who frequently tabulated and commented upon the information provided by Marriage Registers. A century ago, one-third of the bridegrooms and nearly half the brides signed the Registers by marks (32.6 per cent. of men and 48.9 per cent. of women in 1841-5). In the year $1846,32.6$ per cent. of males who married in England and Wales signed by mark; in the industrial county of Lancashire 38.7 per cent. and, in the agricultural county of Norfolk, 42.6 per cent. For women the three percentages are $48.2,65.9$ and 50.9 . In 1871 , the figures for men are $19 \cdot 4,20 \cdot 8$ and $27 \cdot 6$; for women $26 \cdot 8,38 \cdot 4$ and $22 \cdot 1$. At the beginning of this century (1901) the England and Wales percentage for 
males is $2 \cdot 5$, for Lancashire $2 \cdot 4$ and for Norfolk $3 \cdot 3$. The three percentages for women are $2.9,3.8$ and $2 \cdot 1$. In the generation $1846-71$, the improvement in males in the cotton county was greater than in the whole country, but not for women.

A bookish person exaggerates the importance of reading, but it is surely true that town dwellers, before the days of films and picture papers, who could not read, had little chance of educating themselves and probable that, when a third of adults did not sign their names, the proportion of non-readers was large. The reduction of hours of labour, giving time for literary education, must have had a civilizing effect, and we should reckon this an important item on the credit side of industrial legislation. A century later, we realize that the right use of leisure is of primary importance. A legislative expression of this belief has been seen in 20th-century enactments and orders.

It may fairly be said that, long before the end of the 19th century, conditions within factories, the environment of working hours, had been brought up to a standard above those of even the best workplaces in the long war, 1793-1815.

But the general rate of mortality of England and Wales remained until the last thirty years of the century, no better and indeed probably rather worse than in its first fifteen years. William Farr, of course, noticed this and attributed it to the increasing urbanization of the people. He took what comfort he could from the fact that the general rate had not actually increased, as it would have done, if rates prevalent in early 19th-century industrial towns had not improved. But he was always emphasizing the killing power of towns, the positive correlation between density of population and mortality.

Control of domestic sanitation, whether by public opinion or the arm of the law, lagged much more than a generation behind control of conditions in workplaces. In such a book as the late James Niven's 'Observations on the History of Public Health Effort in Manchester' (published in 1923) one has a grim account of Manchester in 1868, of the inhabited cellars, the narrow courts, the privy middens. I content myself with one quotation:

' A vast number of houses are infested by bugs. None of the methods hitherto advocated would seem to meet this plague, which is especially violent in the older parts of the City, as, for example, in Hulme and the Central Districts. . . . These bugridden houses are, many of them, not fit for human habitation, but in the present dearth of houses it will be impossible to get all of them condemned.'

I should perhaps add that this passage refers to the Manchester not of 1868 but of 1923.

Some light is shed on the changes of the last half of the 19th century by statistical comparisons. I know that medical readers dislike tables and that the setting of tables is expensive, so I will eschew them. But any interested reader will be able to see the detail in a more technical paper which will eventually be published.

The age of employment at the middle of the 19th century was virtually from the age of 10 years, and perhaps not many could continue after 55 years, so a comparison of the changes in rates of mortality over the range 10-55 should be instructive; textile industries and female lives shall be taken. As no mere ideal but an attained standard, I have taken the rates of the Registration County of Norfolk, which a century ago (and now) stood among the best for low rates of mortality. As the horrid example-following Farr's practice-I have taken the Registration District of Liverpool. For study were selected Blackburn, Burnley and Rochdale. In these three towns, as recently as 1931 , more than a quarter of the female population was employed on textiles.

We begin with the girls of 10-15. In the decennium 1851-60 the Norfolk rate of mortality (per 10,000 living) was 559, the Liverpool rate 595, the Blackburn, Burnley and Rochdale rates 525, 620, 547. So that, at the beginning of factory life, the cotton towns (except Blackburn) show no disadvantage. At $15-20$, the position is different. Here Liverpool with 716 is better than Norfolk with 785 - perhaps an immigration effect - Burnley, Blackburn and Rochdale with 906, 1045 and 918 worse. At 20-25, Norfolk has 932, Liverpool 948, Blackburn 997, Burnley 1102, Rochdale 995. At 25-35, Norfolk 944, Liverpool 1373, Blackburn 1183, Burnley 1251 and Rochdale 1078. At 35-45, Norfolk has 1090, Liverpool 1877, Blackburn 1491, Burnley 1317, Rochdale 1239. At 45-55, Norfolk has 1207, Liverpool 2686, Blackburn 1796, Burnley 1542, Rochdale 1724. Through half a century these rates improved, but the relative positions did not. Improvement in the country has been as fast as, even, on balance, a little faster than in the textile towns. Thus the rates of young girls in Norfolk for 1891-1900 was 268, in Burnley 247, in Blackburn 258 , in Rochdale 279 , little relative change and the remark applies to the next two age groups. In the age group $35-46$, the relative positions in 1851-60, taking the Norfolk rate as 100 , were Blackburn 132, Burnley 121, Rochdale 114. By 1891-1900-the Norfolk rate had fallen from 1090 to 770 - we reach Blackburn 141, Burnley 127, Rochdale 140. At $45-55$ the position is rather worse; in each town the ratio in 1851-60 was less than 150 , but more than 150 in 1891-1900.

Like most statistical comparisons in time, this is not a wholly adequate test. Centrifugal movements, suburbanization, have a share. But it is perhaps roughly true to say that our fathers and grandfathers did not succeed in diminishing the gap between town and country workers, in spite of the attraction exercised by towns on the more ambitious and presumably healthier young people.

Our generation, which has suffered two wars, may be tempted to look back on the age of the Old Queen as poets of the Roman Empire looked back 
on a golden (mainly agricultural) age. But at least we may claim for this age that the problems of industrial life have been studied as a whole, that it is not only the working hours and the environment of work rooms which are considered the province of the industrial hygienist or legislator.

A casual reader of such a treatise as "The Factories Act, 1937' (by Maddock and Bellhouse) might possibly think that, except in detail, the modern differs little from the old law. As factory legislation eo nomine, is directed to the conditions of the work-place, there must be a close similarity between old and new. But a more attentive reader will notice that hygiene is envisaged more generally and that more effective medical supervision is re- quired than before. The increased responsibility of the Local Authority is of great importance, because it means that, for some important purposes, the Housing Authority and the executive Factory Authority will be identical. In other words, it is no longer true that home and factory are supervised by officials who have no mutual responsibilities. The result is that social legislation and administration are coming to be regarded as a whole. No doubt the synthesis is far from complete. At the beginning of this war, many mistakes of the last war were repeated because knowledge of past experience had not been disseminated, but, without facile optimism, we may believe that the future is promising. 